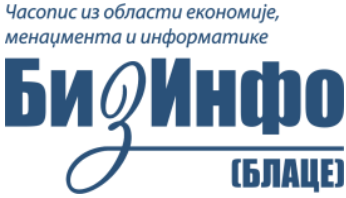

Година 2020, волумен 11, број 1, стр. 31-40

\section{Journal of Economics, \\ Management and Informatics \\ Bizlnfo \\ (BLACE)}

Year 2020, Volume 11, Number 1, pp. 31-40

\author{
Прегледни рад/ Review paper \\ УДК/UDC: 616.98:578.834]:338.124.4 \\ doi: 10.5937/bizinfo2001031H
}

\title{
The global economic impact of COVID-19: Three possible scenarios
}

\author{
Md Sajjad Hosain ${ }^{\mathrm{a} *}$, Md Rasel ${ }^{\mathrm{b}}$ \\ ${ }^{a}$ Business School, Sichuan University, Sichuan, China \\ ${ }^{\mathrm{b}}$ College of Commerce, Ningxia Vocational Technical College of Industry and Commerce, \\ Ningxia, China
}

\begin{abstract}
This theoretical paper aims at reviewing and forecasting the possible economic after-impact of COVID-19 worldwide. It is entirely based on published sources such as articles, online and print information (e. g. information published on newspapers, Internet and different TV channels). The long last economic impact this viral outbreak is yet to be known as such dreadful news will possibly show up only after once it slowed down or completely wiped out although some of them have already been visible. In this paper, the author predicts three possible scenarios that the world economy might face. He has also provided some action recommendations for the individual Governments and economic organizations in order to reduce (as such loss cannot be prevented completely) the aftereffects of such deadly catastrophe that shows up once in a century. The paper is expected to assist as a baseline for further research attempts to be made regarding the economic impact of COVID-19 by the academicians and guide the policy makers to make some recovery plans. Keywords: COVID-19, Coronavirus, Economic impact, Global recession, Virus outbreak.
\end{abstract}

\section{Introduction}

It has been already a very well known fact that the COVID-19 (popularly known as Coronavirus) was originated in the city of Wuhan, the capital of Hubei province in China during the end of November, 2019. At present (end of March, 2020), the name (COVID-19) has become a shocking and terrifying invisible enemy for the mankind and the world itself. The world has been badly hit by this infectious disease with 558,502 confirmed cases and 25,251 confirmed deaths around 200 countries as on 27 March, 2020 (WHO, 2020) when this paper is being written. While at this moment, the humankind is conscious about its life threatening power, very little is known yet

${ }^{*}$ Corresponding author.

E-mail address: sajjad_hosain@yahoo.com 
regarding the after-effects particularly the financial and economic losses (Hafner \& Krstić, 2013). However, obviously, some of the immediate effects of this outbreak have been already visible as the front line impacts such as loss in production, closure of local and international flights, postponing of big events including sports tournaments and disturbance in financial services due to the infectious nature of the virus. As the first international whistle blower, the Paris based international organization "Organization for Economic Co-operation and Development" (OECD) has warned the possible losses to international economy due to the outbreak in its Economic Outlook database published in March 2, 2020. The organization warned that the world economy is at risk and there is a strong possibility that the global growth rate might be reduced to half of the previous prediction due to the interruption in production and financial sectors (OECD Economic Outlook, 2020). It has been warned that the growth rate may be lowered from an already weak $2.9 \%$ to 2.4\%. Since the beginning of COVID-19 in China in November, 2019, the virus has invited not only substantial losses in human lives, but also has resulted in noteworthy economic disturbance from quarantines, restrictions on travel, factory closures and a sharp decline in many service sector activities. Such a lower prediction puts the global economy on the border of a recession that has been conventionally defined as "growth below 2.5\%". Therefore, the fear of another global recession due to total lockdown in global economy cannot be ignored at all.

This paper has highlighted the tentative impacts of this viral outbreak on different industries in a global basis and puts a few suggestions on how to recover from such losses. The paper has been divided into some sections. This paper has discussed the possible economic direct and indirect impacts of COVID-19 worldwide. In addition, the author has put some predictive scenarios that might take place due to the outbreak and finally puts a few recommendations for the policy makers to overcome the economic losses due to this viral outbreak.

\section{Literature review}

Due to the longer practice of globalization and interconnectivity of the multinational corporations as well as well as countries, no country can ignore the incidents/losses/damages that take place in another part of the globe. Firms are interrelated through trade within and across sectors with specialized productions (Hosain \& Hossain, 2019). For an instance, a product can be assembled in one country but the components may be produced in another country or countries (Hossain \& Hosain, 2019). We can simply put one example here. The components of an iPhone are manufactured in 5 countries as shown in table 1.

Table 1. The manufacturing locations of iPhone's components worldwide

\begin{tabular}{cc}
\hline Country & Components \\
\hline USA & Glass screen, Wi Fi chips, audio chips \\
Japan & Camera, Compass, LCD screen \\
China & Battery \\
Germany & Accelerometer \\
Switzerland & Gyroscope \\
\hline
\end{tabular}

Source: lifewire.com 
Therefore, any disturbance at one point of the supply or production can shock the entire production process due to its severe inter-connectivity (Suhaeli \& Kurniati, 2015). Although the new cases of infection in the mainland China is decreasing, the new confirmed cases around the world is increasing in geometric proportion. In addition, it should be considered that due to the outbreak of this deadly virus in mainland China from November, 2019 to March, 2020 (3 months), the production and supply of major raw materials from China to the rest of the World have been severely disrupted or stopped. As a result, what was originally thought as a largely China-centric upset has now been admitted as a global crisis by many economic experts and researchers. The spread of the virus has undesirably borne out many analysts' downside scenarios where investors digesting the implications of severely broken supply chains, executive restraint actions and spillovers from the real economy to financial markets. The decision by major energy producers to uphold present levels of production in spite of falling prices has further scared investors while questions about the Governments' abilities to mount an effectual and coordinated response been delayed. Such amplified uncertainty has led to financial market instability last evident only during the global financial crisis in 2008 (Segal \& Gerstel, 2020).

\section{The tentative economic impact}

A difficult question has already taken place in the minds of analysis' and policy makers is that what will be the extent of damage done by COVID-19 in global economy. Such a question is very difficult to answer due to its highest level of uncertainty and the change of direction. The degree of the spoil will mostly depend on how rapidly and efficiently the virus is enclosed, the measures authorities take to control it and the extent of economic support the Governments are willing to deploy during the epidemic's instant impact and afterwards. However, the direct and immediate effects can be visible in Chinese mainland. Early indications of COVID19's shock on the Chinese economy are much inferior than it was initially forecasted. Surveys of Chinese manufacturing and services sector (reuters.com) estimated to record lows in February while automobile sales was reduced to a record $80 \%$ (bloomberg.com); and China's exports fell $17.2 \%$ in January and February (Bermingham, 2020). The executive data confirmed an extensive hold back in economic actions followed by the lower pollution levels and decreased shipping movements, among other unofficial indicators. As a consequence, analysts have compelled to sharply adjust down estimates of Chinese growth, with a strong predicting a drop in first quarter GDP, the first reduction since China started reporting economic data on a quarterly basis since 1992. Worse news is that since the virus spreads worldwide, China's economic revival might be further challenged as demand from other countries drops as they also have to deal with the same virus. Therefore, although the outbreak seems to have been controlled inside China, COVID-19 and its impacts have now spread globally.

The virus infection and death is now severely a common scenario in all over Europe, Asia and the United States where the concerned authorities are implementing aggressively containing measures in order to contain the spread of virus. So far, Europe (Goodman, 2020) and Japan (Fujioka, 2020) are most possibly 
already in recession terrain based on their fragile fourth quarter performance and higher dependence on trade. While the United States entered the crisis scenario with a tailwind (US Bureau of Labor Statistics, 2020) some analysts (Lahart, 2020) are predicting a narrowing US GDP in the second quarter. However, estimates of the global impact vary. Earlier last week, the Organization for Economic Co-operation and Development (OECD) projected (OECD Interim Economic Assessment, 2020) that COVID-19 will narrow down global GDP growth by one-half a percentage point for 2020 (from 2.9 to 2.4\%) whereas Bloomberg Economics warns (bloomberg.com) that a full-year GDP growth could drop to zero in a worst-case pandemic circumstance.

Figure 1. Global GDP growth projection

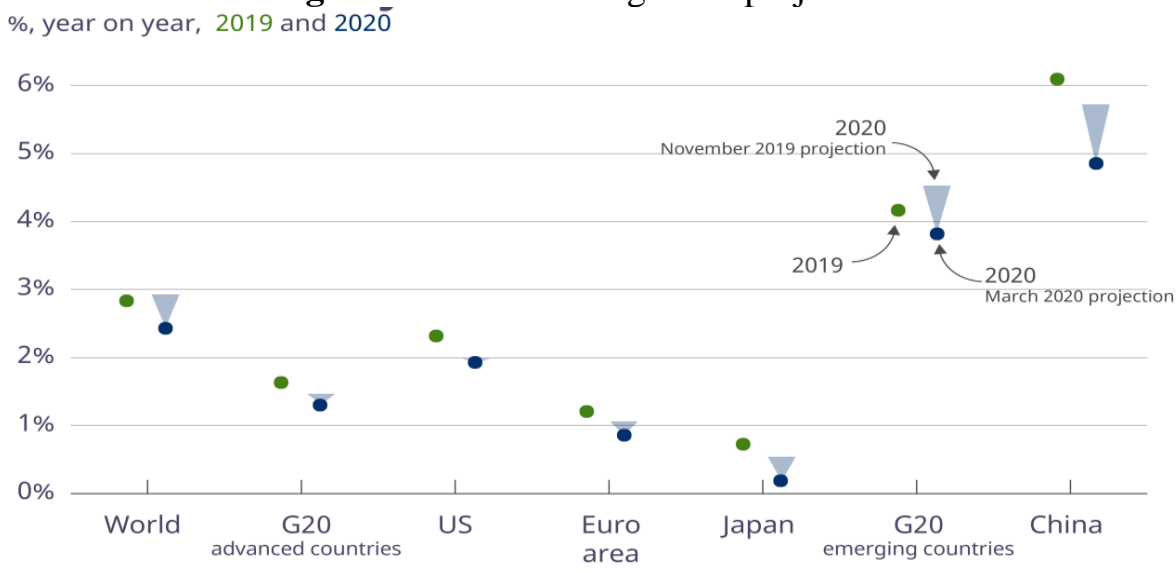

Source: OECD Economic Outlook database

Source: OECD Economic Outlook database

Sector-wise shocks

Most likely, COVID-19 could affect the global economy through four possible shocks directly. Some of the most acute ones have already been evident to the world. There might be some other indirect impacts. However, the following sub-sections have been utilized to highlight those negative effects occurred due to the virus outbreak.

1. Decrease in global production: The most direct and severe impact of the virus outbreak is the sharply reduced production of goods. In most cases, many production factories have been totally shut down not only in mainland China but also most parts of the globe. Chinese production has already been significantly impacted due to the long term lockdown in most areas including the Hubei province. Some other countries in Asia and Europe have also started to feel a direct impact since the concerned authorities are taking similar measures. The lower production in China has significantly affected exporters to China. China's biggest sources of imports are Korea, Japan, and other Asian countries. Thus, even without new outbreaks of the disease, these areas will likely experience slow growth in the first half of 2020 (Bacman, 2020). 
2. Disruption in supply chain: As it a well known fact that a number of manufacturing firms depend on imported transitional inputs from China and other countries affected by the deadly infection (e.g. Japan, South Korea, Germany). On the other hand, many companies also rely on sales in China to mitigate their financial goals. The slowdown in economic activity as well as restrictions in transportation affected countries will most possibly to have an impact on the production and profitability of specific global companies, particularly those involved in manufacturing and in raw materials required in manufacturing. For companies that depend on intermediary goods from affected regions not able to easily switch sourcing, the size of the disruption may rely on how rapidly the outbreak fades and situation come into normal. Small and medium enterprises (SMEs) may have superior difficulty in surviving the circumstance. Travel and tourism industry is facing the worst losses that are likely not recoverable in the near future.

3. Financial impact on firms and financial markets: Temporary disruptions of inputs and/or production might strain some firms, predominantly those with insufficient liquidity. Individual traders in financial markets may or may not properly foresee or understand which firms might be in danger. The resultant rise in risk might disclose that one or more key financial market players have taken investment positions that are not conductive under current conditions. Such wrong decisions may further weaken the trust in financial instruments and markets. A likely event would be a noteworthy financial market disruption since participants become anxious about counterparty risk. A rather more possible likelihood is a momentous fall down in equity markets and corporate bond markets. In such cases, the individual investors would likely to hold Government securities or bonds due to the uncertainty created by the pandemic. Since March, 2020, most stock markets around the world have shown unusually negative indices that are very unlikely and indicated the loss of general investors.

4. Indirect effects: Among the indirect effects due to the virus outbreak, the most dangerous one is the loss of jobs due to the slowdown or shutdown in manufacturing and financial sectors. Another slow but long term impact is the lower consumption of goods and services due to the lower or no income of individuals resulting from job losses. In addition, half of the world population is staying at home in fear of virus attack. Such confinement means lower consumption which is not conductive for and may have a circular negative impact on the country-wise or global GDP.

\section{Tentative scenarios due to outbreak}

The author has put some potential scenarios that are purely expressive ideas about possible future circumstances in the global economy due to CODID-19 outbreak around the globe. Such possibilities are solely the probabilities based on the projections on present measures taken to prevent the infection by the various Governments.

Scenario 1 (Controllable rapid recovery): The economy will return to normal despite of slow economic growth and reduced production. This is the best possible scenario that the world can expect. The good news is that the local transmission in 
China has almost reached to $0 \%$. Although some remote outbreaks are still taking place inside China, such infection does not necessarily create severe spread of the disease. China's economy is slowly returning to normal and some factories are being permitted to continue as regular. China's GDP takes a big hit in the first quarter of 2020 but expected to bounce back in the second and third quarters. Although some companies outside mainland China experience short-term supply disruptions, the impact on the global economy is expected to recover soon once the outbreak come under control.

Scenario 2 (Moderate recovery with severe impact): The second likelihood is the moderate economic recovery with severe impact. Although we can observe the spread of the disease in China has gone down, such outbreaks are already severe around the world particularly in Europe and US. Each outbreak requires slowing production in that infected area and since we live in a globalized world, this indicates rolling disruptions to different regions and industries. The resulting general impact is to disrupt economic activity sufficient to sluggish global growth considerably. In such scenario, the businesses that are agile enough to manage switching suppliers having sufficient liquidity to survive periods of low sales and revenue will have a competitive advantage.

Scenario 3 (The recession): The third and most disastrous scenario for the world economy is the recession that might take place due to virus outbreak. At present when the paper is being written, the outbreak is in a higher form in most of the countries as noted earlier. More than half of the world population is under total lockdown including many manufacturing zones and financial centers due to panic over the spread of the virus. Uncoordinated decisions on a country-by-country basis are most likely to disrupt the movement of both people and goods. Global manufacturing will decline, as businesses with international supply chains can function only irregularly. Travel, tourism and related industries have almost lost with millions of amid fear of millions of jobs to cut. If, unfortunately, the disease would last a year or more, we should prepare for such hard time. Global GDP will go down, international trade will fall and a global recession is a distinct possibility.

Postponed shipments and production schedules will create financial troubles for companies with heavy debts, particularly in the United States. A major decline in global equity markets may compel the investors selling assets such as high-yield bonds and volatile stocks which in turn, may expose investors who have underpriced risk. Concern about counterparty risk accelerates the decline and dries up liquidity in financial markets. If, the Central banks are unable to solve such problems efficiently and timely, the global financial market and the economy might observe a V-shaped recession.

\section{Practical recommendations}

The world is watching one of the worst disasters taken once in a century. Therefore, the losses in lives as well as economy are bound to be enormous. But as human, we can only hope for the best option and prepare for some practical measures to recover from such disaster. This section has been used to make some action 
recommendations for the policy makers and business owners that might come to some help. The recommendations have been divided into short term and long term measures.

\section{Short term measures}

Such initiatives can be taken to avoid or prevent the short term losses made by the virus infections mostly to save lives and survive the small businesses. Such measures might range from providing cash incentive to removing the consumption/value added taxes (Stojković et al., 2013) as instructed by various authors in emergency economic situations.

1. Cash incentive: A good and effective measure can be to provide emergency cash incentive to the individuals and SMEs to survive and buy the daily necessities. Such a measure has already been taken by different Governments including the US. US Senate has recently passed a bill to release $\$ 1$ trillion to help families in the US. The assistance can be $\$ 1000$ depending on the family size. The White House is also planning for another bill that can provide $\$ 300$ billion for small businesses, $\$ 50$ billion in loans for cash-strapped airlines and $\$ 150$ billion for loan guarantees to other distressed economic sectors (Channel News Asia, March, 2020). For temporary survival, such initiative can be taken in order to revive the economy. Such cash incentive might also prevent the employers from job cut thereby reducing the fear individuals to be jobless.

2. Removal the interest for short time: For a short period of time, for example, 6 months to 1 year, the interest amount can be removed for the money borrowed by the small businesses from banks and other financial institutions. Such interests can be paid by the local or central Governments in order to motivate the SMEs for well survival and continue their usual businesses.

3. Rationing: The local authorities should put strong rationing system in order to avoid access buying habits amid fear of lockdown. Such excessive buying that are purely unnecessary that cause pressure on the consumer products and ultimately raises the price. We have seen in many countries that the selves are already empty due to the unnecessary bulk purchases by the people. The authorities should put strict control on the amount buying depending on the family demand.

4. Reduction in personal and corporate tax bracket: Another short term measure the policy makers can consider is reducing the personal and corporate tax bracket (scope). It can be an effective indirect incentive that the Ministries of Finance can consider due to this stronger and uncertain attack on personal income for many lower income groups.

\section{Long term measures}

The long term measures in order prevent or slow down the negative impacts can be usually taken on the basis of more than one year. Unlike short term measures narrated above, the results from these measures can only be seen in a longer period. 
1. Interest rate cut: A good initiative can be a substantial interest rate cut by the Central Banks. Such cut can encourage the businesses to take loan from the banks and invest in regular production and/or financial activities. In addition, interest rate cut might indirectly encourage the firms engaging in production activities that are conductive for related businesses such as suppliers of raw materials and intermediate buyers.

2. Increasing the amount of public works: If the duration of infection and lockdown is longer than expected, a good initiative can be the creation of mass public/Government works once the outbreak is controlled. As it has been mentioned on the previous paragraph, when large numbers of manufacturing/construction (e. g. roads, bridges, larger buildings, dams etc.) works are initiated, they help the other related businesses to revive. For example, if the Government takes mass public construction around the country, it will help other industries such as steel, iron, bricks, cement, electric appliances, paint and so many others to manufacture and supply their productions to the core construction projects (Kitanović \& Krstić, 2010). As a result of all these, existing jobs will be retained and new job will hopefully be created as well.

3. Removal of consumption/value added taxes: Without any doubt, the aftereconomic shock of any emergency situation is severe. Most of the experts feel that the consumption of consumer goods will largely drop after COVID-19 will disappear. One tested cure for such lack of demand is to reduce the price resulting in inspiring general consumers to buy more. As we all know, higher consumption leads to higher production and higher production leads to higher GDP and generation of employment. Therefore, this paper proposes that the Governments may temporarily reduce or remove the indirect taxes such as consumption tax (Stojković et al., 2013) or value added tax (VAT). Such a measure can help to increase consumption in an after COVID-19 hit economy.

4. Increasing the research fund for scientific investigation: An obvious fact COVID-19 has taught us that we have to increase the research fund on scientific investigation in order to defeat the threat of such virus infections. Such investment can reduce largely the threat and loss of lives that, in turn, would save the economy. The authorities should understand that life is not for economy, but economy is for life.

\section{Theoretical and practical implications}

The paper is an attempt to highlight the economic impacts and projected scenarios caused by COVID-19. The author hopes that this discussion paper based on the published sources will act as a foundation for further academic and research investigations regarding the impacts. In addition, the policy makers may also consider the recommended measures in respective circumstances whether they are implementable or not. 
The paper is based on only published sources. In future, empirical investigations can be made based on the official data and published information in order to analyze the economic impact more deeply taking a larger scope.

\section{Conclusion}

COVID-19 will certainly reduce a substantial portion of world GDP. Many ecumenists believe that it will at least one-third of the previously predicted one. At least for the shorter period, many sectors will have to cut employments due to reduced production and limited financial operations. The longer effects are yet to be estimated depending on the existence of the outbreak followed by global lockdown.

The world has seen such a deadly lockdown and disruption only after the Second World War. It is obvious that the longer the outbreak is, the severe the damage in the economy will be. As humans, we can only hope that the best will happen. The positive side is that many Governments are working together and extend their helping hands to cooperate another. The World Health Organization (WHO) has branded COVID-19 as the common enemy number one for the human. Therefore, we can expect that all the countries will work and fight together against such invisible enemies at all times.

\section{References}

Bacman, D. (2020). The economic impact of COVID-19 (novel coronavirus). Deloitte. https://www2.deloitte.com/us/en/insights/economy/covid-19/economicimpact-covid-19.html

Bermingham, F., (2020). Coronavirus: China's exports and imports plummet in January and February. The South China Morning Post https://www.scmp.com/economy/china-economy/article/3074060/coronaviruschinas-exports-and-imports-plummeted-january-and

Bloomberg. (2020). China car sales drop record $80 \%$ as virus empties showrooms. Retrieved March 28, 2020, from https://www.bloomberg.com/news/articles/2020-03-04/china-car-sales-drop-arecord-80-as-virus-adds-to-industry-woes

Bloomberg. (2020). Coronavirus could cost the global economy \$2.7 Trillion. Retrieved March 28, 2020, from https://www.bloomberg.com/graphics/2020coronavirus-pandemic-global-economic-risk/

Channel News Asia (2020). US Senate passes one COVID-19 aid package while working on another. Retrieved March 28, 2020 from https://www.channelnewsasia.com/news/world/coronavirus-covid-19-unitedstates-aid-package-12554196

Fujioka, T. (2020). Japan's GDP contraction revised to $7.1 \%$, fueling recession fears amid coronavirus crisis. The Japan Times Retrieved. https://www.japantimes.co.jp/news/2020/03/09/business/economybusiness/japan-gdp-recession/\#.Xu6TJWgzbIU

Goodman, P. (2020). Europe is probably in recession. Can its leaders move fast and deliver relief? The New York Times Retrieved 
https://www.nytimes.com/2020/03/09/business/europe-recessioncoronavirus.html

Hafner, P., \& Krstić, M. (2013). World economic crisis and post-crisis concepts. Ekonomika, 59(4), 76-85.

Hosain, M. S., \& Hossain, M. S. (2019). US-China trade war: Was it really necessary? International Journal of Business and Economics, 4(1), 21-32. https://doi.org/10.5281/zenodo.2590676

Hossain, M. S., \& Hosain, M. S. (2019). US-China trade conflict: The bottom line. Journal of Business and Economic Management 7(6): 243-249. https://doi.org/10.15413/jbem.2019.0160

Kitanović, D., \& Krstić, M. (2010). The impact of the exchange rate on the economic growth of Serbia. Economic Themes, 48(1), 13-29.

Lahart, J. (2020). The virus aftermath won't be like a hurricane. The Wall Street Journal https://www.wsj.com/articles/the-virus-aftermath-wont-be-like-ahurricane-11583529896

Lifewire (2020). Where do iPhone components come from? Retrieved March 28, 2020, from https://www.lifewire.com/where-is-the-iphone-made-1999503

Organization for Economic Co-operation and Development. (2020). OECD Economic Outlook, 2020. Retrieved March 28, 2020, from http://thecircular.org/oecd-the-world-economy-is-at-risk-recession-due-to-covid$\underline{19 /}$

Organization for Economic Co-operation and Development. (2020). OECD Interim Economic Assessment: Coronavirus: The world economy at risk. Organization for Economic Co-operation and Development. https://www.oecd.org/berlin/publikationen/Interim-Economic-Assessment-2March-2020.pdf

Reuters. (2020). China February activity contracts at record pace as coronavirus bites. Retrieved March 28, 2020, https://www.reuters.com/article/us-chinaeconomy-pmi-factory-official/china-february-factory-activity-contracts-atrecord-pace-as-coronavirus-bites-idUSKBN20N03R

Segal, S., \& Gerstel, D. (2020, March 10). The Global Economic Impact of COVID19: Critical questions. Center for Strategic \& International Studies. https://www.csis.org/analysis/global-economic-impacts-covid-19

Stojković, A., Gašić, M., \& Perić, G. (2013). The place and role of the consumption taxes in contemporary tax systems. Ekonomika, 59(1), 231-239.

Suhaeli, D., \& Kurniati, B. N. (2019). Why do (not) woman entrepreneurs jump into technology based business? Bizinfo (Blace) Journal of Economics, Management and Informatics, 10(2), 95-109. https://doi.org/10.5937/bizinfo1902095S

US Bureau of Labor Statistics (2020). Economic News Release: Employment Situation Summary. Retrieved March 26, 2020, https://www.bls.gov/news.release/empsit.nr0.htm

World Health Organization. (2020). Coronavirus disease (COVID-19) pandemic. https://www.who.int/emergencies/diseases/novel-coronavirus-2019

Received: 8 April, 2020; Sent for Revision: 16 May, 2020; Accepted: 5 June, 2020 